\title{
ON HOLY BOUGHS AND SACRED FOOLS: VIRGINIA WOOLF UNDER THE SHADOW OF JANE HARRISON*
}

\author{
Isabel $\mathrm{M}^{\mathrm{a}}$ Andrés Cuevas**
}

\begin{abstract}
Insofar as the influence of myths and ritualistic practices on Modernist artists becomes evident, this paper explores the still underestimated degree of convergence between Harrison's theories, as a direct inheritor of Frazer's major postulates, and some of Virginia Woolf's fictional works.

Indeed, whereas some descriptive outlines of such connection have been carried out, the present analysis aims to reach further by examining the narrator's particular form of appropriation —occasionally through sheer mockery and subversion - of such traditions, which will undoubtedly shed light on Woolf's actual apprehension of the society of her time.
\end{abstract}

Key words: Modernism, fiction, society, Virginia Woolf, Jane Harrison, Ritualist school, Carrying Out the Death, Tyiades, Festival of Fools, King of the Bean.

Resumen: En tanto que la influencia de los mitos y prácticas de índole ritual en los artistas del Modernismo resulta innegable, el presente artículo explora el aún infravalorado grado de convergencia entre las teorías de Jane Harrison, directa heredera de los postulados de Frazer, y algunas de las principales obras narrativas de Virginia Woolf.

En efecto, mientras que se han llevado a cabo algunos estudios descriptivos, este artículo pretende ir más allá a través del análisis de la particular forma de adopción de dichas tradiciones por parte de la narradora - incluyendo la patente mofa y subversión de dichas tradiciones, lo que, sin duda, contribuirá a arrojar luz sobre la auténtica noción de Woolf con respecto a la sociedad de su tiempo.

Palabras clave: Modernismo, ficción, sociedad, Virginia Woolf, Jane Harrison, Escuela ritualista, Expulsión de la muerte, Tíades, Fiesta de los Locos, Rey del Haba.

[...] and then on the terrace, as if popping out to breathe the air, to glance at the garden, came a bent figure, formidable yet humble, with her great forehead and her shabby dress - could it be the famous scholar, could it be $\mathrm{J}-\mathrm{H}$ - herself? (Woolf 1996: 16).

Whether these initials, ascribed to the lady at Fernham in Virginia Woolf's A Room of One's Own, correspond or not to the influential anthropologist Jane Harrison, the imprint

* Fecha de recepción: abril 2005

Fecha de aceptación y versión final: junio 2005

** Becaria, Departamento de Filologías Inglesa y Alemana, Universidad de Granada; $₫$ iandres@ugr.es 
of the classical scholar on Woolf is nowadays beyond any doubt. K. J. Phillips, discussing the relevance of Harrison within the Modernist circle, identifies Fernham, the woman's college in Woolf's work, with Newnham, founded in 1872 and based on Cambridge, where the scholar arrived two years later (Phillips 1991: 465-6). Similarly, Shattuck remarks the contact between them through visits and letters, which points to a relationship probably transcending pure acquaintance. In addition — she observes - Woolf had read Harrison's Epilegomena and kept a copy of Ancient Art and Ritual in her library, while in 1925, the Hogarth Press also published the first work by the anthropologist, the so-called Reminiscences of a Student's Life (Shattuck 1987: 279).

Whatever the degree of intimacy of their relationship, which is ultimately subordinated to pure speculation, the truth is that Virginia Woolf admired the achievements of a woman who had suffered the discrimination of a male-restricted university education, and accordingly, praised her as one of the most intellectually powerful women of her time (Phillips 1991: 465-6). In fact, the study of ancient myths and ritualistic practices was very much in tune with the growing interest in anthropology which had spread among modernist artists and writers. Under the ritualist school ${ }^{1}$, Harrison contributed to develop Frazer's conceptions of myths as post hoc rationalizations (Macclancy 2003: 80), whereby, whereas ritual practices die out with time, the mythical residue associated with them remains throughout religion, art, and literature.

Of its permanence through the latter, no doubt, some of Virginia Woolf's novels constitute a reliable, yet underestimated testimony. Particularly, we will focus attention on Mrs. Dalloway (1925), Between the Acts (1941), and Orlando (1928), on the basis of their providing valuable evidence of the trace of Harrison and her anthropological theories on Woolf's thought, as well as on her adaptation of mythological elements and rites. Thus, in her 1913 Ancient Art and Ritual, Jane Harrison points out, on describing the Spring Festival celebrated in Greece, the role of the Dythirambs, which she defines as "the Song and Dance of the New Birth” (Harrison 1913: 101). Indeed, she remarks, in the savage world, it was of vital importance that every member of the tribe unexceptionally undergo two different births. Hereby, after the first, or biological coming into existence, the individual experiences a second rebirth, this time of a social nature. As Harrison herself explains: "With the savage, to be twice born is the rule, not the exception. By his first birth, he comes into the world, by his second, he is born into his tribe. At his first birth he belongs to his mother [...]; at his second he becomes a full-fledged man and passes into the society of the warriors of his tribe" (Harrison 1913: 104).

As an initiation rite, this practice finds continuity in the presentation of Elizabeth at Clarissa's party. Introduced by her mother to both Peter and the reader as "my Elizabeth”, Clarissa's daughter appears at the beginning of the novel as a dependent, a shy girl who hardly dares to address a timid salutation to her mother's friend. Moreover, her interests are closer to a child's rather than to the typical concerns of a young woman. Hence, while

\footnotetext{
${ }^{1}$ The ritualist school was integrated by a group of Cambridge scholars who shared a common interest in the discoveries of anthropology and their application to myth and literature. This society, which soon evolved as a progressive movement, developed into three generations of teachers, mentors, and collaborators, among whom authors such as Jane Harrison, G. Frazer, E. B. Tylor, or Robertson Smith clearly outstood as the leading figures.
} 
Clarissa admits to a passion for gloves and shoes, 'her Elizabeth' "cared not a straw for either of them" whereas it is her dog — Clarissa reflects — that "Elizabeth really cared for [...] most of all" (Woolf 1912: 12). Yet, through her appearance at the party towards the end of the story, Elizabeth is born into a completely new grown-up woman, sexually attractive to the eyes of her father, initially unable to recognize his own daughter: "For her father had been looking at her, [...], and had thought to himself, who is that lovely girl? And suddenly he realised that it was his Elizabeth, and he had not recognised her, she looked so lovely in her pink frock!" (212).

The theme of the twice-born recurs in the whimsical novel Orlando. Originally born as a man, Woolf's androgynous character re-emerges as Lady Orlando after undergoing a ritual ceremony majestically presided over by "the Gods who keep watch and ward by the inkpot of the biographer" (Woolf 1995: 65). Moreover, with the narrator's underlying purpose of ironical exaggeration, Orlando also experiences what can be considered as a third rebirth, this time with more evident social connotations, once he becomes officially declared as a woman (126). Under the form of sexual inversion, the second birth becomes a leit-motif in the novel. Thus, the until then Archduchess Harriet arises later as Archduke Harry (87). Similarly, Orlando's discovery of Marmaduke Bonthrop Shelmerdine as formerly a woman, brings to the fore Shel's transformation.

On the other hand, the unsettling image of the toad inside the snake's body in Between the Acts suggests a form of second birth. However, the logical progression of the ritual is in this case destroyed through the ironically grotesque twist implied by a death-oriented pregnancy: "There, couched in the grass, [...] was a snake. Dead? No, choked with a toad in its mouth. The snake was unable to swallow; the toad was unable to die" (89).

Yet, if the introduction into society was valuable for ancient tribes to the extent of being considered as a second birth, it was no less essential that members should maintain their community skills in order to be regarded as socially alive. On the contrary, Harrison notes, as soon as these tribal members began to lose their social abilities, they became inexistent for the rest of the community. As Harrison puts it - "a man dies socially when he ceases to be able to dance his tribal dances" (1921: 16). In this sense, it is possible to establish a parallel with Septimus, "the outsider" and society-ostracised due to his inability to dance to the rhythm of Holmes's and Bradshaw's metaphorical tune artificially composed around deeply-rooted conventions, such as war glory, social prestige, economic status, or patriarchal conceptions of marriage, as denoted by Holmes's remarks: "(h)e had actually talked of killing himself to his wife, quite a girl, a foreigner, wasn't she? [...]. Didn't one owe perhaps a duty to one's wife?" (Woolf 1992: 101).

Significantly, Sir William performs a ritualistic worship of traditional values in the form of the Goddesses Proportion and Conversion, whose dictates endow the doctor with superhuman power. Indeed, Woolf's narrator stresses that:

[w] orshipping proportion, Sir William not only prospered himself, but made England prosper, secluded her lunatics, forbade childbirth ${ }^{2}$, penalised despair, made it impossible for the unfit to propagate their views until they, too, shared his sense of proportion $-[\ldots]$ so that

\footnotetext{
2 Emphasis added.
} 
not only his colleagues respect him, his subordinates fear him, but the friends and relations of his patients felt for him the keenest gratitude [...]" (1992: 109).

The depiction of Bradshaw's power, particularly regarding his control over childbirth, echoes Frazer - one of Harrison's main sources - and his account of the Egyptian myth of $\mathrm{Ra}$, the god who, jealous of Nut's affair, cursed the goddess against giving birth to her child, the later Osiris. As the legend goes - according to the anthropologist - Osiris was born during the intercalary days thus arranged by the ancient Greeks on the basis of a superstitious impulse that compelled them to equal the duration of both the lunar and the solar years (Frazer 1913: 341). A similar combination of astrology and superstitions is also suggested in Between the Acts. Lucy Swithin, who personifies herself a number of these irrational beliefs, such as that of touching wood, serves as a point of convergence for similar cosmic-religious rituals. Hence, her portrayal at the beginning as wearing "a cross gleaming gold on her breast" prepares for the ritual act she magically performs. Furthermore, it is precisely in the 'intercalary' moments between the acts of La Trobe's pageant that Lucy, who suddenly becomes a "majestic goddess, rising from her throne among her peers", ceremoniously heals William. Indeed, this is accomplished through Mrs. Swithin's offer to the sun-god, represented by "the yellow gravel that made a crescent round the door" (66) on which she fixes her eyes, at the same time as her cross is magically struck by the sun.

Furthermore, on one occasion, Lucy's rite of fingering her cross, as well as the allusion to God on his throne through Isa's reflections, as in most of the rituals observed by Harrison and Frazer, is connected with the coming of the rain. Indeed, not accidentally, the very character of Lucy Swithin embodies the homonymous Saxon saint traditionally associated with the rainy season and around whom a sort of magical-pagan legend was formed. As the folk tale goes, when the bishop was laying on his deathbed, he asked to be buried outdoors, where he could be rained and trodden on. Yet, after nine years, the monks of Winchester, the saint's bishopric, decided to remove his remains to a shrine inside the Cathedral on $15^{\text {th }}$ July 971. According to the legend, from then a heavy rain was bound to accompany either the ceremony or its anniversary, from which a superstition-imbued formula derived that if it rains on St. Swithin's day, it will remain for forty days in succession, whereas a fine $15^{\text {th }}$ July will be followed by forty days of fine weather. Moreover, the same ritualistic tone permeates the events in Pointz Hall, which significantly also take place in the middle of the summer, while the remark on the yearly repetition of the question about the weather - "And which would it be, wet or fine?"- contributes to reinforce the ineludible incantatory power of a formula which, at the time of the narration, has invariably recurred seven times: "(e)very summer, for seven summers now, Isa had heard the same words" (20). Indeed, Pointz Hall lodges the same burial rite, initiated by Lucy's decision to show Isa and William her house, since "it was time to fulfil her promise" (62). As they mount up the staircase, funeral music is suggested through the subtle combination of a veiled allusion to descent, along with the musical reference:

She [Lucy] panted slightly, going upstairs. Then she ran her hands over the sunk books in the wall on the landing, as if they were pan pipes.

'Here are two poets from whom we descend' (63). 
Additionally, at a certain moment, Mrs Swithin becomes aware of the "invisible procession" leading her to bed, at the same time as she spontaneously prompts into a most significant reference to "[a] bishop, a traveller":

'Now up, now up again.' Again they mounted. 'Up and up they went', she panted, seeing, it seemed, an invisible procession, 'up and up to bed.'

'A bishop; a traveller; - I've forgotten even their names. I ignore. I forget' (63-64).

Thus, if the tribe members analysed by the anthropologists longed for the rain so that their crops may grow, the villagers in Between the Acts, though, actually desire the lack of it -hoping that the pageant, Miss La Trobe's harvest, will neither be spoilt:

Mrs. Swithin's eyes glazed as she looked at [the sky]. Isa thought her gaze was fixed because she saw God there, God on his throne. But as a shadow fell next moment on the garden Mrs. Swithin loosed and lowered her fixed look and said

'It's very unsettled. It'll rain, I'm afraid. We can only pray', she added, and fingered her crucifix (21).

In her accounts of ritual practices, Jane Harrison insists on the pragmatic nature of ritual and its character as mediate, that is, as a means to achieve an end (Phillips 1991: 472). Hereby, the figure of the scapegoat mostly develops as the embodiment of a desire for renewal, as an essential prerequisite for the assurance of fertility and, consequently, of the prosperity of the crops. It is precisely Osiris, the God whose birth had been initially forbidden, that Harrison defines as a central scapegoat figure, or the "prototype of the great class of resurrection gods who die that they may live again" (1913: 15).

Analysing Between the Acts, Madeline Moore points to the presence of the Isis-Osiris myth as a token of the theme of fertility in the novel, whereby Isis - embodied by her almost homonymous Isa- "represents the rich plants of Egypt made fruitful by the annual inundation of the Nile, which is Osiris" (1984: 156). In Mrs. Dalloway, Woolf re-enacts the myth through the character of Septimus, "the Lord who had come to renew society" (27). Like the effigy of Osiris, which is to be removed and destroyed at the end of the year, Septimus realises, self-assuming his role as a scapegoat, the fate that awaits for him: "It is I who am blocking the way, he thought. Was he not being looked at and pointed at; was he not weighted there, rooted to the pavement, for a purpose?" (16).

In Ancient Art and Ritual, Harrison continues to define Tammuz - the Babylonian equivalent of Osiris - as "the true son of the waters", representative of a "life that springs from inundation, and that dies down in the heat of the summer" (1913: 19). Similarly, Septimus is often connected with a sea-related origin through his recurring portrayal as "a drowned sailor". In addition, his death takes place in June, though he reminds himself the Cymbelian formula "Fear no more the heat of the sun", at the prospect of a renovative death. After his destruction, conceived, in resemblance to Harrison's account of the rite, as a passage "below the earth to the place of dust and death", the goddess Ishtar "went after him, and while she was below, life ceased in the earth, no flower blossomed and no child of animal or man was born" (Harrison, 1913: 19). Once he has died, Ishtar-Clarissa undergoes 
a similar trip towards her companion by means of her reflection about Septimus's death: "But this young man who had killed himself — had he plunged holding his treasure [....] She had escaped. But that young man had killed himself. Somehow it was her disasterher disgrace" (202-203).

Retired from the party, life becomes suspended for Clarissa, who immerses herself into a temporary extinction: "(d)eath was defiance. Death was an attempt to communicate [...] 'If it were now to die, "twere now to be most happy"' (202).

Attempting to arrive at a definition of the scapegoat, both Frazer and Harrison insist on its utility as the physical realization of evil and death, which is to be rejected and driven away as a means of expelling the negative values from collective life. On describing the rites of the Greek Charila, developed with this purpose, Harrison explains: "(T)he childimage of 'Charila' is brought in [...], the king struck the image with his sandal, the leader of the Tyiades lifted the image and lifted it away to a precipitous place, and there tied a rope round the neck of the image and buried it [.... It is clearly a 'Carrying out the Death'", (1913: 80).

Not accidentally, Septimus is carried down into Hell by his apocalyptic visions of flames and Dantesque horrors. In addition, after the verdict of humankind has been announced - "human nature had condemned him to death" (99), the expiatory victim feels "(t)he whole world was clamouring kill yourself, kill yourself, for our sakes" (101). Furthermore, the form of his death is neither chosen at random. Indeed, Septimus's flinging himself through the window retains a surprising parallel with the Spring Feast of Ascension in Transylvania described by Harrison (1913: 69), where a representative puppet of the Death is similarly thrown out of a window: "I'll give it you! He cried, and flung himself vigorously, violently down on to Mrs. Filmer's area railings" (164). As in the Transylvanian rite, Septimus's body is as well plunged into a river, ceremonially transfigured into the round shape of a coin: "She [Clarissa] had once thrown a shilling into the Serpentine" (202).

In resemblance to the grammatical rules of Greek language, which so much fascinated Woolf (1993: 179), the theme of the scapegoat undergoes a process of 'reduplication'. Hereby, it is not only enacted by different characters throughout her novels, but additionally, recurs in the form of different allegorical allusions to the expiatory lamb. It is significant how Rezia, in her attempt to make her husband centre his attention on reality, has him look at what turns out the reflection of his own self as a scapegoat: "'Oh look, she implored him. But what was there to look at? A few sheep. That was all" (28). The remark constituted by the last two sentences evidently deprives the image of its solemnity and mystery, ultimately reducing the motif to its purely physical and most ordinary dimension. This mocking tone is reinforced by the image of cattle appearing during Clarissa's party. Not at random, one of the guests turns out to be a painter, a device that allows Woolf to include as well the lamb motif in its artistic dimension. Depicted as "the fine old fellow who had produced more bad pictures than any other two Academicians in the whole of St. John's Wood", Sir Harry appears no more dignified than the image of the lambs/cattle in his paintings, which show a deplorable picture of an absurdly stereotypical meek-and-mildness: "[his pictures] were always of cattle, standing in sunset pools absorbing moisture, or signifying, for he 
had a certain range of gesture, by the raising of one foreleg and the tossing of the antlers, 'The Approach of the Stranger'” (192).

Contemplating the pragmatic side of the Spring Festival in Greece, as rituals promoting fertility, Harrison notices the existence of different traditions and procedures. Hence, she holds, "(y)ou may 'bring back' the life of the Spring in the form of a tree or a maiden, or you may summon her to rise from the sleeping Earth" (1913: 78). The latter, which she calls the "Rising-up" form tended to be the most common type among ancient Greeks, particularly as connected with the myth of Persephone, Demeter's daughter, who is carried below the Earth and risen up year after year. The scene, which is recurrently displayed on Greek vasepaintings - Harrison explains — represents "[a] mound of earth [...] sometimes surmounted by a tree; out of the mound a woman's figure rises; and all about the mound are figures of dancing daemons waiting to welcome her." Observing the description of this scene, there is no doubt that the representation of the myth as yielded by Harrison served for Woolf as a source of inspiration in the construction of her female vagrant in Mrs. Dalloway, that: "voice of no age or sex, the voice of an ancient spring spouting from the earth [...] which issued [...] from a tall quivering shape, like a funnel, like a rusty pump, like a wind-beaten tree for ever barren of leaves who lets the wind run up and down its branches singing [...] and rocks and creaks and moans in the eternal breeze" (89).

This rising-up woman who has remained there "through all ages [...] singing of love which has lasted a million years" clearly represents the perennial figure of the Earth mother that fosters the fertility of the land and enables the continuity of life. Moreover, embodying simultaneously the image of the rising tree, as well as the earth-rising woman -whose mouth is perceived as "a mere hole in the earth, muddy too" (89) - this vagrant-Persephone recalls through her song "how once she had walked in May, where the sea flows now" (90). Certainly, this song constitutes a clear allusion to the spring prosperity celebrated through the ritual festivals. On the other hand, Frazer also notes a similar rite to foster the rain and the growth of crops among the Cora Indians in Mexico. The festival, which, like the story in Mrs. Dalloway, also takes place in June, is led by: "two old women, who represent the goddesses of sowing by digging holes in the earth with long strikes and inserting the seed of the maize in the holes; whereupon a man who represents the Morning Star pours water on the buried seeds. This solemn dance is accompanied by the singing of an appropriate hymn [...]" (Frazer 1913: 238).

To argue whether Woolf employed this precise variant of the ritual when she conceived the character of the vagrant remains beyond the scope of this paper. Yet, the truth is that the primeval woman in Mrs. Dalloway considerably fits into the pattern of the sowing women - though fused into one figure. Moreover, if in the case of the Indian women, fertility was boosted through ritual dances, similarly, the vagrant's hymn becomes essential. Indeed, identified by H. Miller as Richard Strauss's Allerseelen, an evocation of the encounter of the dead lovers on All Souls' Day (Miller 1982: 190), this ancient song, as it bubbles from the "muddy" mouth of the woman: "still the earth seemed green and flowery [...], matted with root fibres and tangled grasses, still the old bubbling burbling song soaking through the knotted roots of infinite ages [...], stream[s] away in rivulets over the pavement [...], fertilising, leaving a damp stain" (89). 
Partly due to his identity as an expiatory victim, Septimus's portrayal is intimately dovetailed with Frazer's grotesque Fool and his depiction of the King of the Bean. The direct successor of the King of the Saturnalia, this Carnival personage is ultimately defined by the anthropologist as "a burlesque figure personifying the festive season, which after a short career of glory and dissipation is publicly shot, burnt, or otherwise destroyed, to the feigned grief or genuine delight of the populace" (Frazer 1913: 312). Certainly, Septimus has also enjoyed his moment of glory - "'You served with great distinction in the War?'” (105) - Bradshaw reminds him. Yet, as is typical of the double nature of the King of Carnival, he is also metaphorically beaten. Hence, besides adopting a vexatious patronising attitude towards his patient, the suddenness with which the doctor performs his "curious exercise with the arms, which he shot out, brought sharply back to his hip, to prove [...] that [he] was master of his own actions" entails a suggestion of implicit violence. Moreover, Dr. Holmes becomes for the ex-combatant "a repulsive brute, with blood-red nostrils" (101). On certain occasions, he feels "Holmes was on him", at the same time as the doctors become terrible beasts who "scour the desert [and] fly screaming into the wilderness" (107).

Discussing the influence of Harrison on Woolf's Between the Acts, Sandra D. Shattuck identifies Mrs. Manresa and Giles as the respective Queen and King of the May Festival. She also highlights that it is in the pageant that this connection is for the first time pointed by the narrative voice. Meanwhile - she notes - implications of this pageant constituting a dance around the Festival maypole are suggested by the dance of actors and chorus that takes place around the Queen on her soap box, at the same time as the words "a-maying, amaying" are sung (Shattuck 1987: 284).

Yet, the novel, which as Shattuck stresses, retains considerable similarities with Harrison's postulates, also includes other Kings of Bean. Hence, Giles, who in his kicking game ends up striking himself, constitutes another image of the beaten King of Carnival: "The first kick was Manresa (lust). The second, Dodge (perversion). The third himself (coward). And the fourth and the fifth and al the others were the same" (Woolf 1992: 89). Additionally, Woolf also places at the pageant in Pointz Hall a patent fool, embodied by Albert, the village idiot. There can be little doubt that Woolf was actually influenced by the anthropological observations of Jane Harrison and her accounts of spring rituals when she has the audience discussing Albert's participation in the pageant assure: "The idiot [...] He's in the tradition" (100).

Throughout his study of Saturnalia-derived Spring Festivals, Frazer observes the existence in France of a Festival of Fools, during which clerical authority became mimicked and ridiculed. In these celebrations, Frazer states, "dominated its whimsical phases, the grotesque and sometimes impious masquerades, the merry and often disgusting scenes, the furious orgies, the dances, the games, the profane songs, the impudent parodies of the Catholic liturgy". One of the distinguishing notes of these festivals, as described by Frazer, consisted in the mingling of clergy and laymen, who act, dance, and play without the usual divisions (1913: 312). Hence, Reverend Streatfield, who also participates in the village pageant in Between the Acts, becomes utterly deprived of authority. His discourse, rather than persuasive or intimidating, is half-blown with the wind. In addition, the evident signs 
of his attachment to human pleasure, his tobacco-stained fingers, confirm him as one within his peers. Moreover, through his exposure, Streatfield becomes an unexceptional - even grotesquely vulgar - figure, object of mockery for both his audience and the surrounding elements:

The Rev. G. W. Streatfield, a piece of traditional church furniture; a corner cupboard; or the top beam of a gate, fashioned by generations of village carpenters after some lost-in-themiddle-of-antiquity model.

He looked at the audience [...] The whole lot of them [...] felt embarrassed, for him, for themselves. There he stood [...] a butt, a clod, laughed at by looking-glasses, ignored by the cows, condemned by the clouds [...] An irrelevant forked stake in the flow and majesty of the summer silent world (171).

Nevertheless, it is through Albert, the acknowledged idiot letting free that unacted part in each of us (179), that the most irreverent attack against religious authority is enacted. Frazer, whose hypotheses are consistently followed by Harrison, observes that "(a)mongst the buffooneries of the Festival of Fools one of the most remarkable was the introduction of an ass into the church, where various pranks were played with the animal" (1913: 335). Accordingly, the pageant in Between the Acts also involves the participation of a fake donkey, whose appearance in the middle of Mr. Hardcastle's prayer suggests the practice previously described. Despite the narrator's questioning whether it was “intentional [...] or accidental [...]", the fact is that "the hindquarters of the donkey, represented by Albert the idiot, [becoming] active" during the religious performance constitutes a blasphemous parody of religious officialdom (153-4).

If the Feast of Fools partly aimed at destroying the authority of the church, Frazer locates the major concern of the traditional King of the Bean around the decrowning and debasement of political power, which is mocked and parodied (Frazer 1913: 312). This definition certainly matches the rendering of the Prime Minister at Clarissa's party. A ridiculous figure, he becomes the object of buffoonery of the narrative voice: "One couldn't laugh at him. He looked so ordinary. You might have stood behind him in a counter and bought biscuits - poor chap, all rigged up in gold lace. And to be fair, as he went his rounds, first with Clarissa, then with Richard escorting him, he did it very well. He tried to look somebody. It was amusing to watch. Nobody looked at him" (188-9).

Occasionally, though, as Frazer notes, the duty of dancing for the growth of the crops is accomplished in Europe and Rome by bands or troops of men. This seems indeed the purpose underneath the troop of marching boys in Mrs. Dalloway, who, just resembling these Roman troopers who "cut their capers for the community" (Frazer 1913: 313), have also sacrificed themselves for the benefit of the whole society through their "renunciation to life" and feelings, in their commitment to "duty, gratitude, fidelity, love of England" (55).

Of course, bearing in mind that the employment of mythological symbols and patterns cannot be interpreted as an unconventional device as concerns a Modernist author like Woolf, yet it is to be noted the particular and innovative use the narrator adopts. Thus, though in certain occasions, Virginia Woolf adheres herself to the conventional form of 
the myth — in which the relationship with Jane Harrison stands as the bedrock- other times, if this passionate apprentice retrieves from below the earth the buried body of the mythological narrative, it is just to reconstruct, and even reinvent the original, so as to offer more accurately her vision of a world, if not completely waste, at least in urgent need of renewal and change.

\section{REFERENCES}

Frazer, J.G. 1913. The Golden Bough. A Study in Magic and Religion. Part IV, The Scapegoat. $3^{\text {rd }}$ ed. London: MacMillan.

Harrison, J.E. 1913. Ancient Art and Ritual. London: Williams \& Norgate 1921. Epilegomena to the Study of Greek Religion. Cambridge University Press.

MacClancy, J. 2003. "Anthropology: 'The Latest Form Of Evening Entertainment"”. A Concise Companion To Modernism. Ed. David Bradshaw. Oxford: Blackwell. 7594.

Miller, H. 1982. "Mrs. Dalloway. Repetition as the Raising of the Dead". Fiction and Repetition. Seven English Novels. Oxford: Blackwell. 177-202.

PhILLIPS, K.J. 1991. “Jane Harrison and Modernism”. Journal of Modern Literature 17, Spring IV: 465-476.

Shattuck, S.D. 1987. "The Stage of Scholarship: Crossing the Bridge from Harrison to Woolf". Virginia Woolf and Bloomsbury. A Centenary Celebration. Ed. Jane MARCus. London: Macmillan. 278-298.

Woolf, 1941. Between The Acts. Ed. Frank Kermode. 1992. Oxford University Press. 1992 (1925). Mrs. Dalloway. Ed. Elaine Showalter. London: Harmondsworth. - (1995) 1928. Orlando. Ed. Merry M. Pawlowsky. Ware: Wordsworth. 1993 (1925). “On Not Knowing Greek”. The Crowded Dance of Modern Life: Selected Essays. Vol. II. Ed. Rachel BowLby. London: Harmondsworth. 